\title{
Durability of Field Resistance to Black Pod Disease of Cacao in Papua New Guinea
}

\author{
J. Saul-Maora and Y. Namaliu, PNG-CCRI, Rabaul (East New Britain Province), Papua New Guinea; and \\ C. Cilas and G. Blaha, CIRAD-CP, TA80/03, 34398, Montpellier Cedex 5, France
}

\begin{abstract}
Saul-Maora, J., Namaliu, Y., Cilas, C., and Blaha, G. 2003. Durability of field resistance to black pod disease of cacao in Papua New Guinea. Plant Dis. 87:1423-1425.

Black pod disease of cacao, caused by various species of Phytophthora, is one of the most serious causes of cacao yield losses worldwide. In Papua New Guinea, such losses on local smallholdings are estimated at more than $40 \%$ of annual production. Genetic improvement of cacao resistance is the most promising way of reducing the impact of these pathogens. Field infection of 25 selected Trinitario $\times$ Upper Amazonian hybrid progenies in a factorial design $(5$ by 5) was monitored for five consecutive years at the Cocoa and Coconut Research Institute in Papua New Guinea. The resistance durability of the various hybrids was analyzed using a factorial split-plot model with years as the main factor. The reaction of the hybrid progenies remained stable and similar throughout the 5 years. Similarly, the general combining ability ranking of the parents was also the same for each year. Moreover, data accumulated over several years provided a clearer distinction between the parents. The analyses clearly showed female inheritance under field conditions, and the progenies from what are believed to be resistant females showed good resistance.
\end{abstract}

Additional keyword: heritability

Black pod disease on cacao is the principal cause of losses in many producer countries. Overall losses are estimated at approximately $30 \%$ of world production (27), hence equal to or greater than 900,000 metric tons of commercial cacao. Control of this disease has been based on the use of genetic resistance and chemical treatment $(4,13,18,20)$. Although complete resistance has not been detected, differences in susceptibility among clones or among hybrids derived from crosses have been observed in various countries, including Cameroon (5), Brazil (28), and Papua New Guinea (29). Thus, genetic improvement of resistance is possible for this trait, which could be transmitted additively (23,31), with narrow-sense heritability values equivalent to broad-sense heritability values up to 0.7 (10).

Several Phytophthora spp. are known to be the causal agents of the disease in Africa, Latin America, and Southeast Asia (6,8,24,25,32). Phytophthora palmivora was found in Papua New Guinea (PNG) in soil under cacao and on infected cacao pods (1). However, damage depends not only on the species of Phytophthora but

Corresponding author: C. Cilas

E-mail: christian.cilas@cirad.fr

Accepted for publication 28 June 2003.

Publication no. D-2003-0923-01R

(C) 2003 The American Phytopathological Society also on the environmental conditions under which the trees are growing, and on climatic conditions during the fruit-producing period. In PNG, black pod disease was recorded in 1924 (7). Its incidence has increased in the 1970s from 10 to $39 \%$ of the pods of open-pollinated Trinitario clones at the Lowlands Agricultural Experimental Station (LAES) located at Keravat, East New Britain province $(15,20)$. Black pod, also called Phytophthora pod rot or "Ppr", caused an annual yield losses in the same area of 15 to 40\% over the period 1988 to 1994 (3).

Therefore, resistance to black pod rot is a priority for the cacao breeding program in PNG (22). Several methods are currently being tested at PNG-Cocoa and Coconut Research Institute (CCRI) to assess cacao genotypes for disease resistance (13), though the reaction of clones or hybrid families under field conditions, evaluated by the percentage of rotten pods, appears to be the most practical. However, to validate such an evaluation method, it is necessary to assess the durability of field resistance in cacao genotypes over several years (11).

The objectives of this work were, first, to estimate the genetics-year interaction and, second, to determine the number of years of records required for an accurate assessment of resistance levels in a defined experimental design.

\section{MATERIALS AND METHODS}

Planting material and experimental design. The progeny from a factorial ( 5 by
5) North Carolina type II experiment were planted in a randomized complete block design with four replications. The main effect was year, and subplots (or secondary effects) were the female and male parents (Table 1) of the 25 families derived from the hand-pollinated crosses between five local Trinitario clones (as female parents) and five Amazonian clones (as male parents) (16). The females and males used in these crosses were of clones selected in PNG for high yield and lower susceptibility to vascular-streak-dieback (VSD) and black pod (22).

The females K82 and KA2-106 were field resistant to black pod, with rates of pod rot of 8.8 and $8.1 \%$, respectively, at 6 to 9 years after planting (19). Other data (17) indicated that K13 was moderately resistant $(15.9 \%$ pod rot) and confirmed the resistance of $\mathrm{K} 82(8.5 \%)$ at 6 to 12 years after planting. The two other female parents were very productive but susceptible to black pod; KA2-101 had $38.6 \%$ pod rot and K24-102 had 58.7\% pod rot at 6 to 9 years after planting (19). The males were upper Amazonian clones selected in PNG and designated as "KEE." These clones had good yields but were either resistant to the disease (KEE 42, 43, and 47 had 5.4, 1.8, and $4.5 \%$ pod rot, respectively, under field conditions in PNG) or were susceptible (KEE 5 and 52 had up to $20 \%$ pod rot) (30).

The trial was set up in 1986 in a 2.9-ha area of field LAES 506 at CCRI near Rabaul in East New Britain province, in four blocks under Gliricidia sepium shade and a cacao tree spacing of 4 by $4 \mathrm{~m}$. In each block, each of the 25 progenies was distributed in elementary random plots of 16 trees (four lines by four rows) (16), so there was a total of 64 trees per progeny in the four blocks. Rotten pods and healthy ripe pods were recorded twice weekly for five consecutive years from 1990 to 1994.

Statistical analyses. In perennial crops, genotype-time (or genotype-year) interactions cannot be estimated easily by a crossing model between these two factors. Indeed, each year the field design remains the same and positive autocorrelations among the consecutive years generally are observed. To study these interactions, a factorial split-plot model $(12,26)$ was adopted, in which the factorial crossing design ( 5 by 5 ) was subordinated to the year factor. Thus, the year was the main factor, and the female and male effects were used as secondary factors of variation. 
Table 1. Black pod rot incidence (in percentage of pods) on 25 hand-pollinated crosses of Trinitario (female) by Amazonian (male) cacao parents in five consecutive years (1990 to 1994)

\begin{tabular}{|c|c|c|c|c|c|}
\hline \multirow[b]{2}{*}{ Parents $^{\mathrm{z}}$} & \multicolumn{5}{|c|}{ Pod rot incidence ${ }^{y}$} \\
\hline & Year 1 & Year 2 & Year 3 & Year 4 & Year 5 \\
\hline K82 × KEE 42 & 8.48 & 4.04 & 3.10 & 5.24 & 5.61 \\
\hline $\mathrm{K} 82 \times \mathrm{KEE} 43$ & 4.72 & 3.40 & 3.89 & 2.51 & 3.69 \\
\hline $\mathrm{K} 82 \times \mathrm{KEE} 47$ & 3.28 & 2.86 & 4.14 & 2.79 & 4.04 \\
\hline K82 × KEE 5 & 5.53 & 1.93 & 3.01 & 1.58 & 2.58 \\
\hline K82 × KEE 52 & 3.70 & 4.17 & 2.77 & 4.92 & 4.15 \\
\hline KA2-106 × KEE 42 & 10.99 & 3.93 & 3.12 & 5.18 & 4.72 \\
\hline KA2-106 $\times$ KEE 43 & 5.57 & 2.15 & 3.75 & 4.38 & 4.42 \\
\hline KA2-106 $\times$ KEE 47 & 3.96 & 2.22 & 3.25 & 3.63 & 4.79 \\
\hline KA2-106 × KEE 5 & 5.27 & 3.45 & 6.21 & 5.02 & 4.40 \\
\hline KA2-106 × KEE 52 & 6.90 & 5.40 & 7.37 & 7.59 & 10.37 \\
\hline KA2-101 × KEE 42 & 5.70 & 4.13 & 4.10 & 4.50 & 5.89 \\
\hline KA2-101 × KEE 43 & 4.71 & 3.69 & 5.95 & 4.65 & 5.47 \\
\hline KA2-101 × KEE 47 & 4.05 & 3.70 & 4.96 & 6.38 & 6.25 \\
\hline KA2-101 × KEE 5 & 7.13 & 6.43 & 9.73 & 9.16 & 7.99 \\
\hline KA2-101 × KEE 52 & 6.09 & 5.85 & 5.94 & 7.35 & 6.20 \\
\hline $\mathrm{K} 24-102 \times \mathrm{KEE} 42$ & 18.27 & 2.41 & 7.04 & 8.86 & 8.45 \\
\hline $\mathrm{K} 24-102 \times \mathrm{KEE} 43$ & 10.64 & 8.12 & 6.92 & 8.42 & 9.47 \\
\hline K24-102 × KEE 47 & 12.28 & 7.24 & 8.21 & 14.05 & 15.70 \\
\hline K24-102 × KEE 5 & 13.33 & 9.94 & 7.06 & 12.23 & 11.14 \\
\hline K24-102 $\times$ KEE 52 & 6.53 & 6.40 & 8.78 & 17.45 & 11.04 \\
\hline K 13 x KEE 42 & 9.56 & 5.09 & 7.00 & 3.12 & 4.57 \\
\hline K $13 \times \mathrm{KEE} 43$ & 15.98 & 6.91 & 5.69 & 6.72 & 7.11 \\
\hline K $13 \times \mathrm{KEE} 47$ & 9.30 & 10.57 & 4.58 & 6.59 & 12.17 \\
\hline K $13 \times$ KEE 5 & 10.40 & 14.28 & 8.44 & 11.49 & 16.66 \\
\hline K $13 \times$ KEE 52 & 5.30 & 5.17 & 5.24 & 7.08 & 7.94 \\
\hline
\end{tabular}

y Mean of four replications per year per progeny.

${ }^{\mathrm{z}}$ Female $\times$ male parents.

Table 2. Factorial split-plot analysis describing temporal variation (year) as main effect and female or male as secondary effects on black pod rot incidence

\begin{tabular}{lrccc}
\hline Factors, source & df & Mean squares & $\boldsymbol{F}$ value & $\boldsymbol{P}$ value $(\boldsymbol{\%})$ \\
\hline Year & & & & \\
Total sub-block & 19 & 183.84 & $\ldots$ & $\ldots$ \\
Year & 4 & 125.10 & 1.90 & 0.174 \\
Block & 3 & 734.48 & 11.17 & $<0.001$ \\
Error 1 & 12 & 65.76 & $\ldots$ & $\ldots$ \\
Female, male & & & $\ldots$ & $\ldots$ \\
Total & 499 & 40.59 & 21.80 & $<0.001$ \\
Female & 4 & 662.32 & 1.15 & 0.333 \\
Male & 4 & 34.92 & 0.97 & 0.490 \\
Year $\times$ female & 16 & 29.45 & 1.53 & 0.087 \\
Year $\times$ male & 16 & 46.45 & 1.37 & 0.156 \\
Female $\times$ male & 16 & 41.49 & 0.59 & 0.99 \\
Year $\times$ female $\times$ male & 64 & 18.03 & 6.05 & $<0.001$ \\
Total sub-block & 19 & 183.84 & $\ldots$ & $\ldots$ \\
Error 2 & 360 & 30.39 & & $\ldots$ \\
\hline
\end{tabular}

Table 3. Factorial analysis of the effects of female and male parents on incidence of black pod rot in 1990-94

\begin{tabular}{lrccc}
\hline Source & df & Mean squares & $\boldsymbol{F}$ value & $\boldsymbol{P}$ value $(\boldsymbol{\%})$ \\
\hline Female & 4 & 126.25 & 11.83 & $<0.001$ \\
Male & 4 & 15.23 & 1.43 & 0.234 \\
Female $\times$ male & 16 & 10.17 & 0.95 & 0.515 \\
Block & 3 & 103.88 & 9.73 & $<0.001$ \\
Error & 72 & 10.67 & $\ldots$ & $\ldots$ \\
\hline
\end{tabular}

Based on the results obtained with the factorial split-plot model, additional analyses using the accumulation of pods recorded over the 5 years were carried out in accordance with common factorial models.

\section{RESULTS}

An analysis of the pod rot rate (Table 1) based on the factorial split-plot model revealed significant block effects, but the year effect was not significant (Table 2). The main results revealed that female-year, male-year, and female-male-year interactions were not significant; hence, the genetic values were relatively stable over time. A significant "female" effect was detected, but the "male" effect and the female-male interaction were not significant.
The nonsignificant genotype-year interaction meant that analyses could be carried out on data cumulated over the 5 years. This combined analysis led to the same results (Table 3); that is, only the female effect was significant, the female-male interaction was not significant, and the broad-sense heritability was equal to narrow-sense heritability. The low heritability value $(0.078)$ was due partly to the fact that the rotten pod rates were relatively low for these progenies $(6.7 \%)$. A highly significant block effect was observed, thus emphasizing the influence of the environment on disease expression in the field.

The narrow-sense heritability directed by the female population was 0.149 , whereas it was only 0.006 for the male population. Analyses of the females for pod rot for each year led to the same classifications as per the 5-year total, but the annual classifications revealed fewer homogeneous groups (i.e., the accumulation of more data over several years enabled a clearer distinction to be made among the parents; Table 4). The analyses revealed the superiority of progeny from K82 (Table 4), which is one of the most field-resistant clones known in PNG $(14,19,29)$.

\section{DISCUSSION}

The analysis of the pod rot incidence over five consecutive years indicated that the genetic effects on disease expression were stable over time. The interactions of the genetic effects with the year factor were not significant, and the parent classification based on their general combining abilities was the same regardless of the year. The heritability of resistance under field conditions increased in line with the number of years records were kept, probably because the pod rot rates calculated on a larger number of pods (over more years) achieved better precision (10).

Significant block effects could have been due to variation in microclimate among blocks, most likely due to variation in shade condition. The combination of significant block effects together with low heritabilities indicates that environmental factors also are very important for disease level in the field.

Field resistance could be linked to several traits, such as fruit susceptibility, the ability of the pathogen to produce inoculum on the tree, or to tree architecture, as well as the pod-bearing period. Consequently, genetic gains for field resistance can be expected from crossing effective parents. However, the significance of the female effect and the nonsignificance of the male effect indicated that pod rot resistance is inherited maternally. Either the males were genetically very similar with regard to disease reaction, or the resistance was only maternally inherited. This second hypothesis was more likely, because an- 
Table 4. Comparison of general combining abilities values of the five female parents (estimated on their progenies) for pod rot incidence across 5 years (1990 to 1994) ${ }^{\mathrm{Z}}$

\begin{tabular}{lcllrrr}
\hline Parent & Year 1 & Year 2 & Year 3 & Year 4 & Year 5 & Total (years 1-5) \\
\hline K24-102 & $11.95 \mathrm{a}$ & $7.98 \mathrm{a}$ & $7.91 \mathrm{a}$ & $13.47 \mathrm{a}$ & $11.34 \mathrm{a}$ & $10.31 \mathrm{a}$ \\
K13 & $10.57 \mathrm{ab}$ & $7.57 \mathrm{a}$ & $6.34 \mathrm{ab}$ & $7.27 \mathrm{~b}$ & $10.30 \mathrm{a}$ & $7.92 \mathrm{~b}$ \\
KA2-101 & $7.09 \mathrm{ab}$ & $5.26 \mathrm{ab}$ & $6.29 \mathrm{ab}$ & $6.82 \mathrm{~b}$ & $6.57 \mathrm{~b}$ & $6.21 \mathrm{bc}$ \\
KA2-106 & $5.94 \mathrm{ab}$ & $3.69 \mathrm{~b}$ & $5.19 \mathrm{ab}$ & $5.48 \mathrm{~b}$ & $5.82 \mathrm{~b}$ & $5.26 \mathrm{c}$ \\
K82 & $5.09 \mathrm{~b}$ & $3.47 \mathrm{~b}$ & $3.66 \mathrm{~b}$ & $3.55 \mathrm{~b}$ & $4.22 \mathrm{~b}$ & $3.80 \mathrm{c}$ \\
\hline
\end{tabular}

$\mathrm{z}$ Values with the same letter in a column are not significantly different according to Newman \& Keuls multiple range test $(P=0.05)$.

other study (30) indicated that there was variation in black pod resistance among the clones used as males. Also, maternal inheritance was earlier described for a vigor trait in cacao (9). However, maternal inheritance of black pod resistance needs to be confirmed because other studies have not shown a maternal effect in the transmission of this trait $(2,10)$, and such maternal effects are uncommon in disease resistance (21). Maternal inheritance could be confirmed by a complete diallel crossing scheme.

\section{ACKNOWLEDGMENTS}

We thank the members of the CCRI Editorial Committee for their critical assessment of the manuscript, the Cocoa Board of PNG for permission to publish, and the staff of the Pathology Section involved in recording field data.

\section{LITERATURE CITED}

1. Arentz, F. 1986. A key to Phytophthora species found in Papua New Guinea with notes on their distribution and morphology. P. N. G. J. Agric. For. Fish. 34:1-4.

2. Berry, D., and Cilas, C. 1994. Etude génétique de la réaction à la pourriture brune des cabosses de cacaoyers (Theobroma cacao L.) issus d'un plan de croisements diallèle. Agronomie 14:599-609.

3. Blaha, G. 1998. Plant Pathology: Overview. In: Annual Report and Research Highlights of the PNG Cocoa and Coconut Research Institute in 1996. Port-Moresby, Papua New Guinea.

4. Blaha, G. 1999. PNG's experience on diseases of cocoa: management through knowledge of use of chemical treatments and resistance in plant material. Pages 305-321 in: Proc. 12th Int. Cocoa Res. Conf., Salvador de Bahia, Brazil.

5. Blaha, G., and Lotodé, R. 1977. Contribution à la connaissance des modalités de la transmission héréditaire de la résistance du cacaoyer à la pourriture brune des cabosses au Cameroun. Café Cacao Thé 21:179-196.

6. Brasier, C. M., and Griffin, M. J. 1979. Taxonomy of Phytophthora palmivora on cocoa. Trans. Br. Mycol. Soc. 72:111-143.

7. Bryce, G. 1924. Cocoa Diseases. Department of Agriculture, Territory New Guinea Leaflet No. 4, Port-Moresby, Papua New Guinea.

8. Campello, A. M. F. L., and Luz, E. D. M. N. 1981. Etiologia de podriadao-parda do cacaueiro, nos Estados da Bahia e Espirito Santo, Brasil. Fitopatol. Bras. 6:313-321.

9. Cilas, C., Amefia, Y. K., and Bertrand, B. 1988. Etude de l'accroissement du diamètre au collet dans un diallèle "quasi-complet" 8 x 8 chez le cacaoyer (Theobroma cacao L.). Café Cacao Thé 32:17-22.

10. Cilas, C., Lanaud, C., Paulin, D., Nyassé, S., N'Goran, J. A., Kebé, B. I., Ducamp, M., Flament, M. H., Risterucci, A.-M., Pieretti, I., Sounigo, O., Thévenin, J.-M., and Despréaux, D. 1998. La résistance à la pourriture des cabosses due à Phytophthora spp. Recherche des composantes de la résistance. Plant. Rech. Dév. 5:441-449.

11. Cilas, C., Verschave, Ph., and Berry, D. 1995. Recherche d'un index de sélection pour deux caractères (production et résistance à la pourriture brune des cabosses) chez le cacaoyer. Pages 333-341 in: Traitements statistiques des essais de sélection. Collection Colloques, ed. Cirad, Montpellier, France.

12. Cochran, W. G., and Cox, G. M. 1966. Experimental Designs. John Wiley \& Sons, New York.

13. Efron, Y., Faure, M., Saul, J., and Blaha, G. 1999. Disease resistance studies and breeding in Papua New Guinea. Pages 181-188 in: Proc. Int. Workshop Contribution Disease Resistance Cocoa Variety Improvement, INGENIC Seminar, Salvador de Bahia, Brazil.

14. Hicks, P. G. 1967. Observations on the diseases and condition of cocoa pods in Papua New Guinea: pod losses. Papua New Guinea Agric. J. 19:5-9.

15. Hicks, P. G. 1975. Phytophthora palmivora pod rot of cocoa in Papua New Guinea: investigations 1962-1971. Papua New Guinea Agric. J. 26:10-16

16. Holderness, M. 1987. Pathology, Trial 206: Heritability of resistance to Phytophthora pod rot. Page 61 in: First Annual Research Report of the PNG Cocoa and Coconut Research Institute. Port-Moresby, Papua New Guinea.

17. Holderness, M. 1990. Plant Pathology: Phytophthora pod rot severity and disease resistance clonal cocoa (Trial 201). Pages 135-137 in: Fourth Annual Research Report of the PNG Cocoa and Coconut Research Institute.
Port-Moresby, Papua New Guinea.

18. Lawrence, J. S. 1978. Evaluation of methods for assessing resistance of cacao (Theobroma cacao L.) cultivars and hybrids to Phytophthora palmivora (Butler). Boletim Técnico 62. CEPLAC-CEPEC, Itabuna, Brazil.

19. McGregor, A. J. 1981. Phytophthora pod rot research in Papua New Guinea since 1971. Pages 129-136 in: Proc. 7th Int. Cocoa Res. Conf. Douala, Cameroon.

20. McGregor, A. J. 1982. Evaluation of fungicides for control of Black pod in Papua New Guinea. Pages 233-240 in: Proc. Int. Conf. Plant Prot. Tropics, Kuala Lumpur, Malaysia.

21. Messiaen, C. M. 1981. Les variétés résistantes. Méthodes de lutte contre les maladies et ennemies des plantes. Institut National de Recherches Agronomiques (INRA), Paris

22. Moxon, J., and Sitapai, E. C. 1985. Research priorities for cocoa in Papua New Guinea. Pages 45-53 in: Proc. 9th Int. Cocoa Res. Conf. Lomé, Togo.

23. NDoumbé, M., Bieysse, D., and Cilas, C. 2001. Multi-trait selection in a diallel crossing scheme of cocoa. Plant Breed. 120:365367.

24. Ortiz-Garcia, C. F. 1996. Etude de la diversité génétique de populations de Phytophthora pathogènes du cacaoyer (Theobroma cacao L.) et du cocotier (Cocos nucifera L.). Thesis, University Paul Sabatier, Toulouse, France.

25. Oudemans, P., and Coffey, M. 1991. A revised systematics of twelve papillate Phytophthora species based on isozyme analysis. Mycol. Res. 95:1025-1046.

26. Philippeau, G. 1982. Théorie des plans d'expérience. Institut Technique des Céréales et Fourrages (ITCF), Paris.

27. Renard, J.-L. 1999. Symptomatologie et incidence économique. Pages 19-75 in: Les maladies des cultures pérennes tropicales. Collection Repères. Cirad, Montpellier, France.

28. Rocha, H. M., Vello, F. 1971. Estudos sobre resistência do cacau (Theobroma cacao L.) a Phytophthora palmivora (Butl.) Butl. Pages 430-438 in: Proc. 3rd Int. Cocoa Res. Conf. Accra, Ghana.

29. Saul, J. Y. 1993. Resistance of cocoa genotypes to Phytophthora palmivora in Papua New Guinea. M.Sc. thesis. La Trobe University, Bundoora, Victoria, Australia.

30. Tan, G. Y. 1992. Cocoa breeding in Papua New Guinea and its relevance to pest and diseases control. Pages 117-128 in: Cocoa Pest Dis. Manage. Southeast Asia Australasia. FAO Plant Prod. Prot. Paper no. 112, Rome.

31. Tan, G. Y., and Tan, W. K. 1990. Additive inheritance of resistance to pod rot caused by Phytophthora palmivora in cocoa. Theor Appl. Genet. 80:258-264.

32. Zentmeyer, G. A. 1988. Taxonomic relationships and distribution of species of Phytophthora causing black pod of cocoa. Pages 391-395 in: Proc. 10th Int. Cocoa Res. Conf. Santo Domingo, Dominican Republic. 